\title{
The Comparative Monitoring of Endem Rare and Endangered Trees and Shrubs in Azerbaijan
}

\author{
Tofig Mammadov, Elman Iskender, and Vagif Novruzov \\ Institute of Dendrology Azerbaijan National Academy of Sciences, Azerbaijan, Baku, Mardakan settle., S.Yesenin \\ str.89, AZ1044 \\ Email: dendrary@mail.az
}

\begin{abstract}
In research work are comparative analyzed rare and endangered trees and shrubs existed in Azerbaijan Republic natural flora, there are analyzed the factors that lead to the disappearance of the species, to the lead of species reduction and disappearance of total families, the risk categories have been identified and defined the solution ways of the problems. There are identified 6,000 species in comparative analysis of Azerbaijan flora. From them more than 1,600 species are trees and shrubs species. It is approximately $37.5 \%$ of the trees and bushes of total Azerbaijan flora. It was revealed that on the basis of monitoring 38 families, 63 genus, 188 species of trees and shrubs should be included in the category of rare and endangered species in the Azerbaijan dendroflora.They are evaluated the current protection status and recommended to be included to the "Red Book" classified by IUCN (2001) adopted categories version 3.1, by taxa classification using of APG III system.
\end{abstract}

Index Terms-flora biodiversity, plant species, Caucasus region, rare and endem species

\section{INTRODUCTION}

Azerbaijan is the richest area in biodiversity in the Caucasus region due of a special plant cover distributed by geographical location, relief, soil and climate conditions. The diversity of flora and fauna species in Azerbaijan and classy endemism are associated with environmental conditions in the area due to the historical evolution.

Despite of the country richness in flora and fauna in the past 30 years they are close to the destruction as a result of irrational, or various natural and human factors rapidly degradation a variety of plant species.

Therefor by impacts of anthropogen factors many of precious trees and shrubs in forests areas Quercus macranthera, Acer trautvetterii, Betula pendula, B.litvinovii,Paeonia mlokosewitschii, Laurocerasus officinalis, Taxus baccata, Pinus eldarica, P. Kochiana,Punica granatum, Cotoneaster saxatilis, Juniperus foetidissima, Pistacia mutica, Rhus coriaria, Rosa spp, Pyracantha coccinea et.c. are extremely reduced.

Manuscript received June 1, 2016; revised January 12, 2017.

\section{MATERIALS AND METHODS}

In research work are used besides of personal research work the references of Azerbaijan prominent botanists studies. In study of flora are used books of "Azerbaijan Flora". T. I-VIII, Baku, 1950-1961, Agamirov U.M., "Azerbaijan trees and shrubs" by Akhundov (II-III Volume, 1964, 1970), Guliyev V. Sh, Khalilov M. Y. "Azerbaijan everygreen trees and shrubs" (1998), Asadov K. S. "Natural fruit plants of Greater Caucasus" (1981), Mammadov F. M. "Dendrology", "Introduction of trees plants in dry subtropics of Azerbaijan"(1990), Safarov I. S., Asadov K. S. "Azerbaijan rare trees and shrubs", Baku, 1984. [1].

Names in Latin of species, genuses and families are given by S.K.Cherepanov (1981) nomenclature.

In classification of plants are used I.A.Gurbanov, K. V. Kiselyova, V. S. Novikov, V. N. Tikhomirov, (T. I-III, 2004, Moscow) "Atlas modifier of trees and shrubs plants".

There are passed a law on Plant protection in 1996 and passed a law in the Azerbaijan National Consitution on 12th november 1995 for the protection of ecosystem and republic environment, for the natural restoration and the conservation of biodiversity.

There are written in addition on 24 march 2006 "The National Strategy and Action Plan" for "The protection of biodiversity, reducing of human impacts on environment and for the purposes of carring scientific-research works in special protected natural zones".

\section{ANALYZIS AND DISCUSSIONS}

Determination of rare trees and shrubs species in the country, preparation of detailed lists of them, the discovery of belonging these plants to rare plant species categories have been carried out by the research works. In order to study these processes in plants we must at first to study plants population spreading, environmental sustainability, physiological tolerance, reproductive biology in later stages of development.

As a result of doing in the country over the last 10 years, 478000 hectares are increasesto 894 thousand hectares of forest areas, it is equal to $11.4 \%$ of the country whole territory [2].

There has been able to avoid by the rerforming of targeted measures and the intensive afforestation works 
the tendency of reduction of Azerbaijan forests and the forest reserves are increased to $0.5 \%$. [3].

In addition there are created 9 National Parks, 11 State Nature Reserves and 20 State Nature Preserves in Azerbaijan. In created special protected natural reserves are conserved the majority of the flora and fauna species entered to "the Red Book". There arecarried out research works by ourselves to determine the protection of trees and shrub species in our republic, by accurate preparation of the records, the discovery of these plants belonging to rare plants category. Natural reserves as it is shown below in Fig. 1.

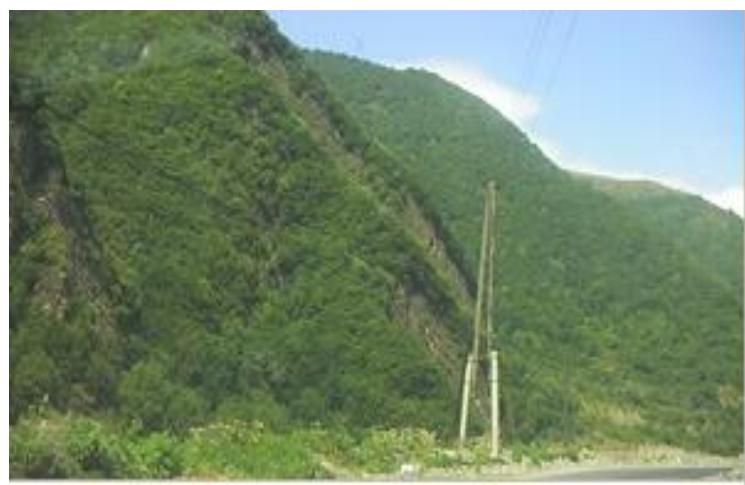

Figure 1. Hirkan forest

There are researched processes by the distribution of plants, largenes of populations, an ecological resistance, physiological tolerance, reproductive biology, the next stages of developments.

There are determined that in 1975 in Azerbaijan Dendroflora were existed 342 species, among them 24 rare and endangered species, in 198428 species, in 1989 45 rare and endangered woody trees and shrub species[4].

There are shown trees and shrubs in natural reserves below in Fig. 2.

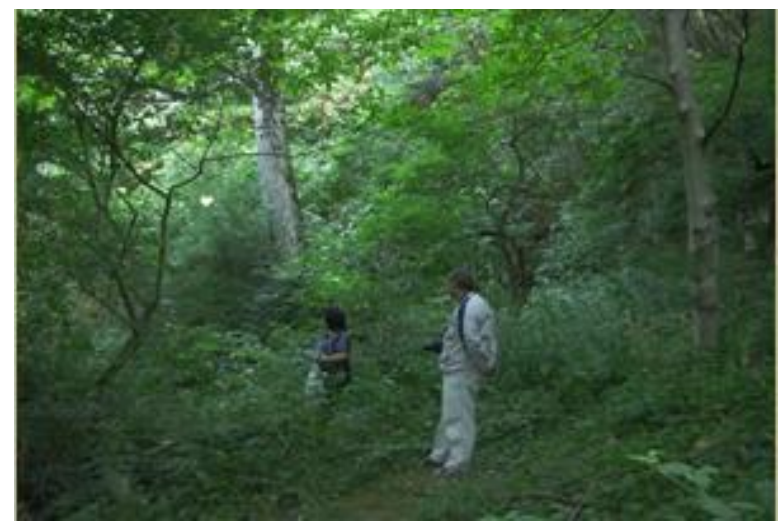

Figure 2. Shahdag national reserve

Currently by the research works are determined that in Azerbaijan Dendroflora are found about 6000 plant species, among them 1600 species are trees and shrub species. They are forming approximately $37,5 \%$ of trees and shrubs of Azerbaijan flora [5].
Recently are estimated the protection status of total flora, 300 plants (266 higher and 20 lower), 14 mushrooms are included to Azerbaijan "Red Book" [6].

By carried research woks are defined that plant species introduced in Azerbaijan flora are forming 68\% species, $87 \%$, genus, $95 \%$ families propagated in nature[7].

Plant species shown below in Fig. 3.

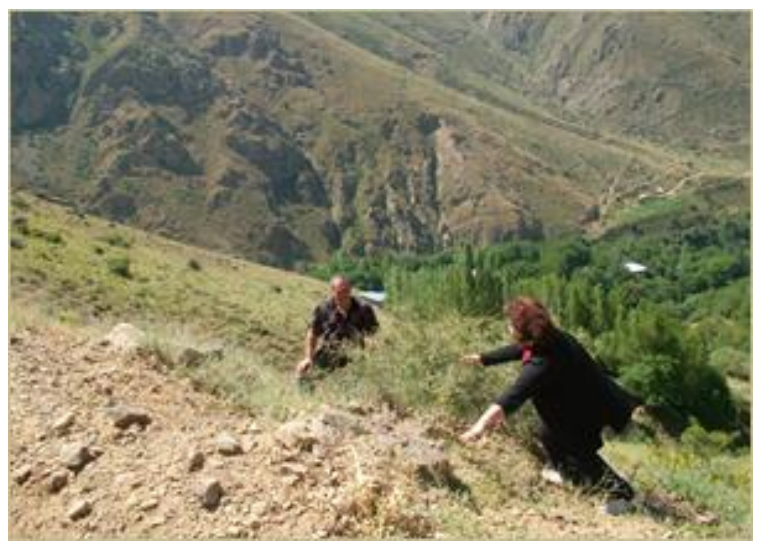

Figure 3. Nakhchevan AR

$25 \%$ of trees and shrubs by specifications are relict in natural flora of Azerbaijan. There are determined by carried research works distributed the of rare and endangered trees and shrubs in Azerbaijan, studied results of the diminishing of distribution areas, endangered factors, defined the threat categories. By research works are used IUCN (2001) 3.1 versions categories and criterias, classification of taxas by APG III system. In addition there are comparative analized Azerbaijan Dendroflora and determined rare and endangered trees and shrubs number of species are 38 families, 63 genuses, 188 species. Among them 67 species are Caucasus endemic, 40 species are Azerbaijan endemic, 4 species are relict.

\section{RARE AND ENDANGERED TREES AND SHRUBS SPECIES}

Araliaceae Juss.

Hedera $L$.

H.helix L.

Hpastuchowii Woronov-

Anacardiaceae Lindl.

Rhus L.

R. Coriaria L.

Pistacia L.

P.mutica Fisch. et Mey.

Aqufoliaceae Bartl

Ilex $\mathbf{L}$.

I.hyrcana Pojark.

Thelycrania Fourr

Th.iberica (Woronow.) Pojark.ex Grossh.

Cornaceae Dumort.

Cornus

C.Meyeri(Pojark) Pilipenko

+Aceraceae Juss.

Acer L. 
A.hyrcanum Fisch.et C.A.Mey.

A.trautvetteri Medw. A.pseudoplatanus L.

A.ibericum

Buxaceae Dumort.

Buxus Pojark

B.hyrcana Pojark.

B.colchica Pojark.

Betulaceae S.F.Gray

Betula L.

B.raddeana Trautv.

B.alba L.(pubescens Ehrh.)

B.microlopis Ig.Vassil. (B.pendula Roth.)

Carpinus L.

C.geoktschaica Radde

C.schuschaensis H.Winkl.

C.macrocarpa H.Linkl.

C.orientalis

Corylus L.

C.colurna L.

Cupressaceae F.W.Neger

Juniperus L.

J.sabina L.

J.foetidissima Willd.

Chenopodiaceae Vent.

Salsola L.

S.cana C.Koch.

S.futilis Iljin.

S.Tomentosa

Celtidaceae Link.

Celtis L.

C.glabrata Stev. ex.Planch

C.australis $L$.

C.tournefortii Lamarck

C.caucasica Willd.

Ephedraceae Wet.

Ephedra L.

E.equisetina Bnuge

E.nebrodensis

Elaeagneceae

Hippophae $L$.

$H$.rhamnoides $L$.

Euphorbiaceae Juss.

Andrachne $L$.

A.telepfoides $L$.

A.buschiana Pojark.

Ericaceae Juss.

Rhododendron $L$.

Rh.LuteumSweet.

Rh.Caucasicum Pall.

Fabaceae Lindl.

Albizia Durazz.

A.julibrissin Durazz.

Astragalus L.

A.beckerianus Trautv.

A.eurylobus Trautv.

A.eurylobus (Barneby)

A.lussiae Rzazade

A.xiphidium Bunge

A.husseinovii Rzazade

A.maraziensis Rzazade
A.igniarius M.Pop

A.terekensis Theod.

A.qudrathi Theod., Fed.et Rzazade-

A.insidiosus (Boriss.) Podlech

A.caspicus M.B.

A.barbacaprina Theod.Fed.et Rzazade

A.vedicus(Takht.) Czer.

A.jucunda (Theod.Fed.et Rzazade) Podlech - A.jucundus

Theod.

A.flavorubens Theod.

Chamaecytisus Link. - (Cytisus L.)

C.caucasicus Grossh.

C.ruthenicus

Colutea L.

C.komarovii Takht.

Gleditsia L. - (Gleditschiana L.)

G.caspica Desf.

Genista L.

G.transcaucasica Shcischk.

G.patula Bieb.

Caragana Lam.

C.grandiflora (Bieb.) (M.B.) D.C.

Fagaceae Dumort.

Castaneae Hill.

C.sativa Mill.

Quercus L.

Q.macranthera Fish. Et C.A.Mey. exHohen

Q.longipesStev.

Q.pedunculiflora K.Koch

Q.pubescens Willd. - (Q.anatolica D.Sosn)

Q.iberica Stev.

Q.crispata Stev.

Q.castaneifolia C.A.Mey.

Q.araxina (Taurtv.) Grossh.

Hamamelidaceae R.Br.

Parrotia C.A.Mey.

P.persica (DC.) C.A. Mey.

Hypericaceae Juss. - (Guttiferae Juss.)

Hypericum $\mathbf{L}$.

H.atropatanum Rzazade

Lamiaceae Lindl. - (Labiata)

Thymus $L$.

Th.karamarianicus Klok. etShost Th.migricus Klok.

Th.fedtschencoi Ronn.

Th.transcaucasicus Ronn. (Th.ziazatinus Klok etShost.)

Th.trautvetteri Klok etShost.

Th. karjaginii Grossh.

Th.daghestanicus Klok et Shost.(Th.hadzhievii Grossh.)

Th.collinus

Limoniaceae Ser. - (Plumbaginaceae Lindl.)

Acantholimon Boiss.

A.tenuifolium Boiss.

A.lepturoides Boiss.

A.fominii Kusn.

A.schemachense Grossh.

Moraceae Lindl.

Ficus $L$.

F.carica $L$.

F.hyrcana A.Grossh.

Nitrariaceae Bercht. etPresl. 
Nitraria L.

N.Komarowii Iljinet lava ex Bobr. - N.schoberi L.

Oleaceae Hoffmgg.etLink.

Fraxinus $L$.

F.coriariifolia Scheele.

Syrinca $L$.

Syrinca persica $L$.

Jasminum $L$.

J.officinale $L$.

Poligonaceae Lindl.

Atraphaxis $L$.

A.spinosa $L$.

A.angustifolia J. etSp.

Calligonum $\mathbf{L}$.

C.bakuense Litv. Calligonum aphyllum (Pall.) Wurke

C.polygonoides $L$.

Rhamnaceae Juss.

Frangula Mill.

F.grandiflora Grub.

Platanaceae Dum.

Platanus $L$.

P.orientalis $L$.

Pinaceae Lindl.

Pinus $L$.

P.eldarica Medw.

P.kochiana Klotzsch ex C.Koch.

Rosaceae Juss.

Cotoneaster Medik.

C.saxatilis Pojark.

Pyrus $L$.

P.boisseriana Bush.

P.elata Pubtz.

P.caucasica Fed.

P.zangezura Maleev.

P.voronovii Rubtz.

P.nutans Rubtz.

P.vsevolodii Heideman

P.eldarica A.Grossh.

P.raddeana Woron.

P.complexa Rubtz.

P.georgica Kuth.

P.medwedevii Rultz.

P.grossheimii Fed.

P.salicifolia Pall.

P.hyrcana Fed.

\section{Sorbus L.}

S.caucasigena Kom.

S.subfusca (Ledeb.) Boiss. S.kusnetzoviiZins.

S.caucasica Zins.

S.luristanica (Borum.) Schonbesk

S.persica Hedl.

Crataegus L.

C.eriantha A.Pojark.

C.caucasica C.Koch.

C.pontica C.Koch.

C.tournefortii Griseb.

Rubus L.

R.buschii (Rozan.) A.Grossh.

R.ibericus Juz.

R.georgicus Focke
R.dolichocarpus Juz.

R.caucasicus Focke

R.persicus Boiss.

R.lanuginosus Stev.ex Ser.

Rosa L.

R.sosnowskyi Chrshan.

R.nisami Sosn.

Rosanizami D.Sosn.

R.alexeenkoi Crep ex. Juz.

R.ruprechtii Boiss.

R.brotherorra Chrshan R.komarovii D.Sosn.

R.kozlowskii Chshan.

R.tuschetica Boiss.

R.sjunikti P.Jarosch.

R.pulverulent aBieb.

R.azerbaidshanica Rzazade

R.sachokiana P.Jarossch. R.marshalliana Sosn.

R.karyaginii Sosn.

R.zangezura Jarosh.

R.oxyodon Boiss.

R.sosnovskiana Tamamsh.

R.buschiana Chrshan.

R.kazaryanii Sosn.

R.hracziana S.Tamamsh.

Padus Mill.

Padus avium Mill.

Prunus L.

P.divaricata Ledeb.

P.caspica Kov.et Ekim.

Amugdalus L.

A.nairica Fed. et. Takht.

A.fenzliana (Fritsch)

Pyracantha M.Roem.

P.coccinea M.Roem.

Salicaceae Lindl.

Salix L.

S.arbuscula L.

S.aegyptiaca L.

S.kyznetzowii Laksch. Ex Goerz

S.caucasica Anders

\section{The SOlution of Problems}

There are prepared as below an action plan which is led to resolve of reduction factors problems of the habitat of rare and endangered species of trees and shrubs, they have the vital importance for the solution of global problems of the modern era:

-The diminishing of Rare and endangered trees and shrub species areas and results of endangered factors and solution methods

-There are determined that rare and endangered woody plant species some sections of areas of Azerbaijan Dendroflora havent conservation strategy.

-Development of industry, building of new settlements are sometimes dangerous for for plants existed in small areas.

-Occupation of $20 \%$ of Azerbaijan territory by Armenia and settlements of 1 million of azerbaijani 
refugies in new areas are strained the threat of plant to one more.

-There are diminished the areas of rare and endangered trees and shrubs, even they are under danger of estinction by the development of tourism in Caspian coastal zone and republic picturesque regions areas, resorts, as a result of building of country houses. Calligonum aphyllum, C. Bakuense species et.cetra.

-Misuse of pasture and meadows are results of extinction of many rare species.

-Use of 800 medicine plant species of Azerbaijan flora are the results of gradually reducing of rare plant species areas.

-Air, water, soil polutions and the extensive use of pesticides are the results of reducing of rare plant species areas.

\section{REFERENCES}

[1] T. S. Mammadov and E. O. Isgender, "Azerbaijan rare trees and shrubs," Baku, 2015, p. 376.

[2] T. S. Mammadov, Dendroflora of Azerbaijan, Baku: Az.USSR Academy of Sciences Publishing, 2011-2016.

[3] G. F. Akhundov, U. M. Agamirov, and A. R. Aliyev, Azerbaijan Trees and Shrubs, Baku: Az.USSR Academy of Sciences Publishing, 1964, vol. 3, p. 221.

[4] "Red Book" of Azerbaijan USSR, Baku, Ishig, 1989, p. 544.

[5] I. I. Karyagin, Flora of Absheron, Publishing of Academy of Sciences of Azerbaijan USSR, 1952.

[6] T. S. Mammadov, Absheron Trees and Shrubs, Baku, Az.USSR Academy of Sciences Publishing, 2010, p. 468,

[7] Flora of Azerbaijan, Publishing of Academy of Sciences of Azerbaijan USSR, Baku, 1950-1964.

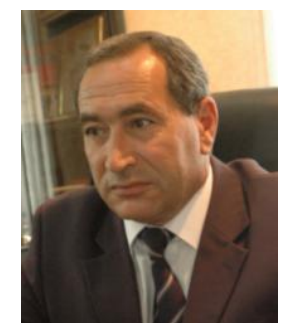

Tofig Sadig Mammadov, director Institute of Dendrology Azerbaijan National Academy of Sciences, was born in 10.02.1957 in Nakhchevan AR of Azerbaijan Republic. He has finished Azerbaijan University of Architecture and Construction in 1974-1982 years, faculty of engineer-architect.

Then he has gained the degree of Candidate of Biological Sciences in 2000, Doctor of Biological Sciences in 2004. He is a Prof.Dr. Correspondent Member of ANAS. The Total number of scientific works are 26 books, 171 papers. Papers published in international journals are 45 . Others are published in local journals. Names of Books are:

T. S. Mammadov, Sh. A. Gulmammadova, "Explanatory terms of anatomy and morphology of plants," Baku, "Elm", 2013, p. 272 .

T. S. Mammadov and E. O. İsgəndər, "Azerbaijan rare trees and shrubs," Baku, "Elm", 2014, p. 380

T. S. Mammadov and H. H. Asadov, "Plants Ecology," Baku, "Elm", 2014 , p. 316.

He is a member of The Caucasus Expert Council of the Botanic Gardens, Bulgaria Poleo-botanical" magazine,Expert Council of the CIS, botanical gardens, experts of Iman University of Kahramanmaras, Sutcu Turkey sections of the journal Nature commission, member of Hortus Botanicus editorial board of the journal and chairman of the Scientific Council of the Arboretum Mərədəkan. Baku State University, the University of the "Odlar Yurdu" (currently) Deputy Chairman of the Department of ANAS Biological and Medical Sciences; the chairman of the Defense Council, Institute of ANAS Botany. Since 2014, the Civil Service Commission under the President of the Republic of Azerbaijan State Civil Service (Ministry of Ecology and Natural Resources) HR Recruitment Department expert.

In 2005, the field of ecology "Man of the Year" award, the order of the Baku City Executive Committee, the Public Association of the Caucasus Heydar Aliyev, Araz Enlightenment Society, Y.H.Məmmədəliyev, H.Zardabi, Sh.I.Xatai orders, the decree of the Presidium of the Academy's honor, the Order of friendship of the Turkic world. 